\title{
A FIRST-EDITION COPY OF ROGER TORY PETERSON'S A FIELD GUIDE TO THE BIRDS, ARCHIVED AT THE UNIVERSITY OF MANITOBA, AND A NOTE ON PETERSON'S CONNECTION TO SASKATCHEWAN
}

SPENCER G. SEALY, Department of Biological Sciences, University of Manitoba, Winnipeg, MB R3T 2N2

Bird watching changed forever in North America with the publication, in 1934, of Roger Tory Peterson's A Field Guide to the Birds: Giving All Species Found in Eastern North America. ${ }^{1}$ Several keys and books designed to aid identification of birds in the field were already available, and bird watching was becoming a popular pursuit, ${ }^{2}$ but Peterson used schematic drawings to depict each species in similar poses, initially, most in black and white but some in colour, of males and females, where their plumages differed. He omitted confusing details to show the bird as it appears to the eye in the field with critical distinctive points emphasized, in some species guided by arrows. Armed by that time with better binoculars, identification of birds in the field became easier, and even more popular. ${ }^{3,4,5}$ Many printings and new editions of the field guide followed and, in 1941, the geographical scope of the book was expanded, focusing on birds found in western North America, which now included all of the species expected to occur in Saskatchewan. The number of subject areas covered by field guides in the "Peterson" series increased in ensuing years and other groups of animals, as well as plants, rocks and celestial features, were treated. Many competing guides, also covering birds in North America, but also in most other regions of the world, have appeared on the market in recent years. This is a testament to the sustained interest in bird identification and other studies of nature by people around the world.

\section{First Edition of A Field Guide to the Birds}

Numerous authors have assessed Peterson's accomplishments, as ornithologist, teacher, wildlife painter, and conservationist. ${ }^{6,7,8}$ The purpose of this article, however, is to examine a rare copy of the first edition of Peterson's field guide (Fig. 1), with its surviving, albeit slightly tattered, dust jacket (Fig. 2), and to add another slant to Peterson's early connection to Saskatchewan. The book is housed in the rare book room of the Archives and Special Collections, Dafoe Library, at the University of Manitoba (catalogued QL 681 P48 1934), and was among a large collection of books and manuscripts donated, in 1995, by Walter R. Henson, a former director of the Natural Resources Institute at the University of Manitoba..$^{9,10}$ Henson received the copy of Peterson's book, and many others, from his uncle, Robert Owen Merriman (1894-1934), a professor of economics at Queen's University and an ardent naturalist. Merriman's bookplate appears on the front end-paper, but the book bears the signature of his sister, Ida Merriman, on a fly-leaf and, below it, an inscription written by Peterson: "For Ida Merriman with my best regards. Roger Tory Peterson" (Fig. 3). Ida Merriman also wrote, on page viii, that "This book is one 


\section{A FIELD GUIDE TO THE BIRDS}

GIVING FIELD MARKS OF ALL SPECIES FOUND IN E.ASTERN NORTH AMERICA

Text and Itlustrations iv Color and is Black and White

BY

ROGER TORY PETERSON

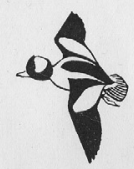

BOSTON AND NEW YORK HOUGHTON MIFFLIN COMPANY

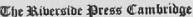

Ida Merriman was impressed by the rarity of her copy of Peterson's book, because on a separate sheet, dated $\mathrm{O}$ ctober 1966, inserted into the book, she re-iterated "This book - "A Field Guide to the Birds" is very valuable because it is of the first thousand [stated as 2000 copies above] printed in the first edition. A correction was made in the "setting" before any more were printed. The correction ... the Whistling Swan has a grey neck. This should be white - the correction was made after the first thousand were printed. This and the fact that the book has the original jacket

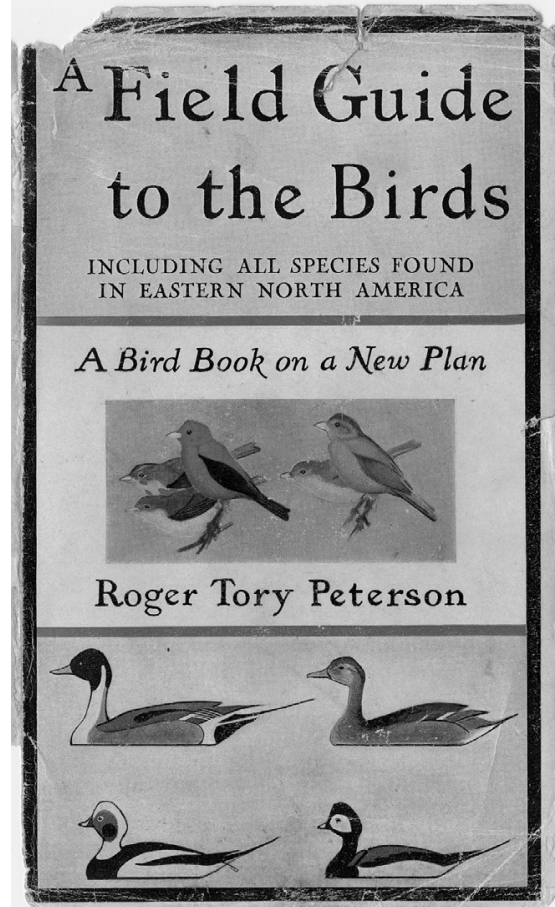

Figure 2. Front page of dust jacket of a copy of the first edition of Peterson's A Field Guide to the Birds. Reproduced with permission from a copy (QL 681 P48 1934) in the rare book room of the Archives and Special Collections, University of Manitoba. 


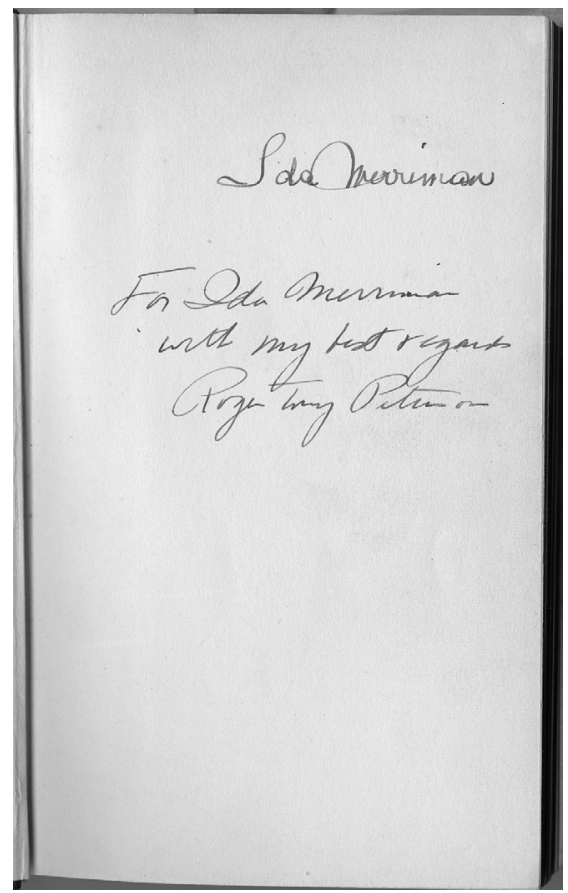

Figure 3. Ida Merriman's signature with Roger Tory Peterson's inscription below.

makes [sic] it very rare." The first edition of Peterson's field guide actually was printed four times, or in four states, or "issues" (each printing had minor corrections), between 1934 and 1939, the year when the second edition was published. Runs of 2000 and 3000 copies were printed for the first and second states, respectively, but the number of copies printed for each of the third and fourth states apparently was not recorded..$^{15}$ The shading on the Tundra [Whistling] Swan's neck (Cygnus columbianus), to which Merriman referred, as well as shading on two species of egrets (facing page 12), persisted through the first two states, but had been corrected by the third printing. (Peterson later confirmed this on page 68 of John Devlin and Grace Naismith's authorized biography The World of Roger
Tory Peterson. $\left.{ }^{6}\right)$ The copy of Peterson's field guide examined here (Fig. 1) can be confirmed as being among the second state on the basis of two changes that were implemented between the first and second states: (1) the year 1934 no longer appears on the title page of the second state (Fig. 1), as it did in the first state, and (2) the corrected "Bog-pumper," denoting the American Bittern (Botaurus lentiginosus), instead of "Bob-pumper," was inserted in its place in the index of the second state, on page 155. Otherwise the two states are identical. The dirty gray plates were corrected before the third printing and the tissue guards that covered the color plates persisted through the first three states, but were replaced with standard paper in the fourth state. All of these errors were corrected when the first revised edition was published in 1939, and the geographical scope of the book was extended westward to the Rockies, so that it passed through Saskatchewan. ${ }^{16,17}$ Details of other variations within editions, states, and printings of Peterson's field guides are available in an online article from the Roger Tory Peterson Institute of Natural History. ${ }^{15}$

\section{Peterson's Connection to Saskatchewan}

Roger Tory Peterson (1908-1996) attended the $77^{\text {th }}$ Stated Meeting of the American Ornithologists' Union that was held in Regina, Saskatchewan, August 25-30, 1959. ${ }^{18}$ Peterson's attendance at the meeting, not surprisingly, was one of the highlights for many people, as C. Stuart Houston recounted in Elizabeth J. Rosenthal's Birdwatcher: The Life of Roger Tory Peterson. ${ }^{8}$ During the opening day of the meeting, Peterson and his longtime field companion, well-known British 
ornithologist, James Fisher (1912-1970), accompanied by Walter J. Breckenridge (1903-2003) of Minnesota, travelled to Old Wives Lake southwest of Moose Jaw where Peterson believed they would have a good chance of finding a few species of birds that were missing from Fisher's life list. Among the seven species they especially hoped to see that day were Greater Prairie-Chicken (Tympanachus cupido), then usually known as Pinnated Grouse, and Sharp-tailed Grouse ( $T$. phasianellus). Peterson was confident that they would find a Sharp-tailed Grouse but, instead, they were surprised to flush a Greater Prairie-Chicken, about $1 \mathrm{~km}$ from the eastern shore of Old Wives Lake..$^{19}$ They never did see a Sharp-tailed Grouse that day!

Peterson and Fisher had met in 1950; their friendship saw them take a 100-day, 30,000 mile odyssey around the periphery of North America, in 1953, from Newfoundland to Alaska by way of Mexico. ${ }^{7}$ They published accounts of their observations, not only of birds and other animals, but also of plants, in Wild America $^{20}$, which was reviewed in Blue Jay by Frank Brazier. ${ }^{21}$ Their attendance at the A.O.U. meeting in 1959, however, was their first visit to Saskatchewan. The highlight at the end of the meeting was the trip to the north end of Last Mountain Lake, where thousands of Sandhill Cranes (Grus canadensis) were viewed as they stopped over during their southward migration. It was not all bird watching that day, however, as Peterson and Fisher relaxed in the shade before lunch in the company of Alexander Wetmore (1886-1978), a former Secretary of the Smithsonian Institution in Washington, D.C. (Fig. 4).

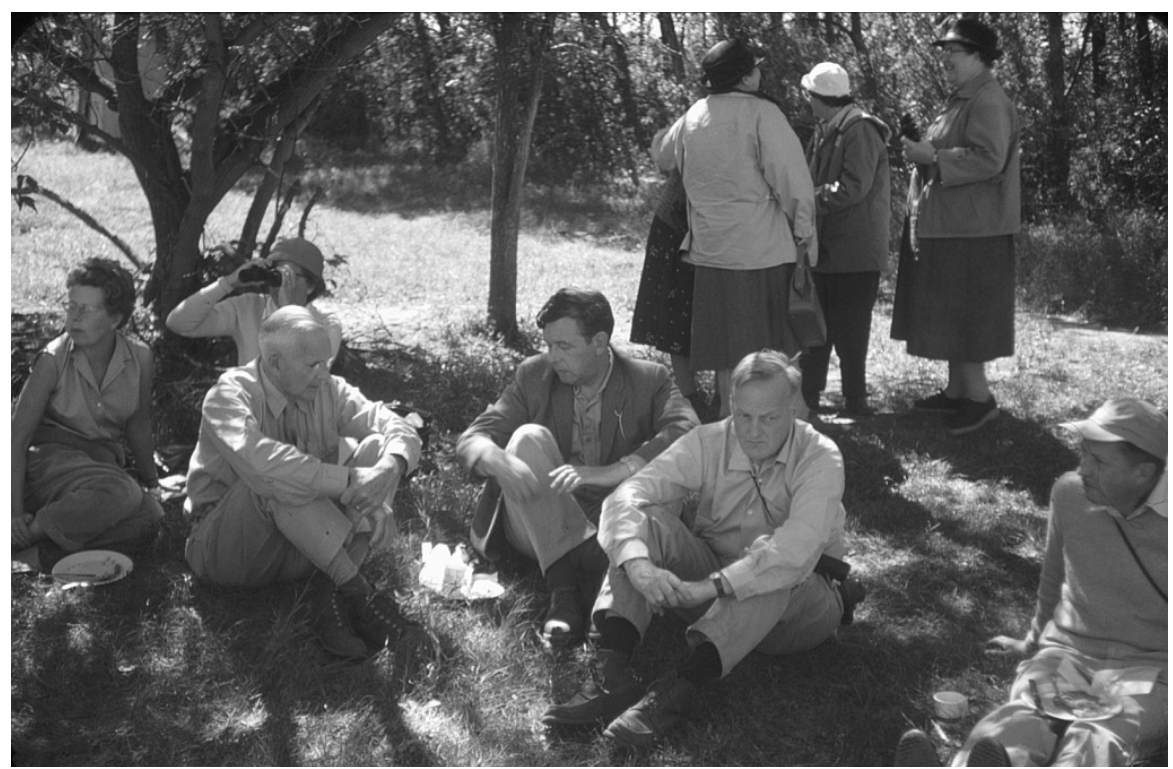

Figure 4. Taking a break after watching Sandhill Cranes at the north end of Last Mountain Lake, Saskatchewan: Alexander Wetmore (seated on the ground at left), James Fisher (centre), and Roger Tory Peterson (immediately to Fisher's right). The identities of the other people in the photograph are not known, 29 August 1959 (photograph by S.G. Sealy). 
Fisher was in awe of the number of cranes seen that day, as elegantly expressed later by John A. Livingston: James Fisher lay on his back in the golden stubble, binoculars trained skyward, and murmured, 'This alone was worth coming 4.500 miles to see.' Above him, slowly and grandly ascending the invisible spiral staircase beneath each puffy cloud, were hundreds of Sandhill Cranes, great wings set as they soared higher and higher toward the altitude they sought for migration southward. ${ }^{22}$

In an editorial published in Blue Jay, Robert W. Nero was reminded of Fisher's statement that few people ever have the pleasure of viewing so many cranes at one time, thus alluding to another, less tangible but important value of wildlife..$^{23}$

\section{Acknowledgements}

I thank Brian Hubner, Shelley Sweeney and staff for facilitating examinations of the copies of the first and revised editions of Peterson's field guide housed in the Archives and Special Collections at the University of Manitoba. Dr. Sweeney also discussed aspects of the provenance of this and other related books in the collection. Tyyne Petrowski provided the scans from the first edition used to prepare Figures 1, 2 and 3 . Daria Wingreen-Mason checked the indices of states of the first edition of the field guide, housed in the Library of Natural History, Smithsonian Institution, Washington, D.C. Mitchell Toda facilitated deposition of the photograph, which comprises figure 4, in the Smithsonian Institution Archives (SIA Accession 13-
099). Martin K. McNicholl commented on an early draft of the manuscript and reviewer, Philip S. Taylor, pointed out an important reference. Glen A. Fox provided companionship at the A.O.U. meeting in Regina and C. Stuart Houston and Robert W. Nero took time from their busy schedules during the meeting to answer our questions. Several young would-be ornithologists attended that meeting amid a welcoming atmosphere. Viewing cranes at Last Mountain Lake and attendance at the A.O.U. meeting count among my earliest and most memorable moments in ornithology.

1. Peterson RT (1934) A field guide to the birds: giving field marks of all species found in eastern North America. Houghton Mifflin Company, Boston, MA.

\section{Barrow MV, Jr. (2000) A Passion} for Birds. Princeton University Press, Princeton, NJ.

\section{Stone W (1934) [Review of]} Peterson's 'Field guide to the birds'. Auk 51:407-408.

4. Taverner PA (1935) [Review of] A Field Guide to North American birds, by Roger Tory Peterson, Houghton Mifflin, Boston. Canadian Field-Naturalist 49:62.

5. Dunn J (1981) [Review of] A field guide to the birds, by Roger Tory Peterson, Houghton Mifflin, Boston. Auk 98:641-642.

\section{Devlin JC, Naismith G (1977)}

The world of Roger Tory Peterson: an Authorized Biography. Optimum Publishing, Montreal.

7. Drennan SR (1998) In memoriam: Roger Tory Peterson, 1908 - 1996. Auk 115:465-469. 
8. Rosenthal EJ (2008) Birdwatcher: the life of Roger Tory Peterson. Lyons

Press, Guilford, CN.

9. Breyfogle D (1995) Collection donated by Professor W.R. Henson. University of Manitoba Libraries, News Release, number 38.

10. Breyfogle D (1995) Henson collection. Manitoba Library Association, Newsline 20(10):8.

11. Bowman RI (1952) Chimney Swift banding at Kingston, Ontario from 1928 to 1947. Canadian Field-Naturalist 66:151-164.

12. Quilliam HR (1974) A history of the Kingston Field Naturalists. Blue Bill 21:26-31.

13. McNicholl MK (1994a) Bird-banding and bird observatories in Ontario: 1905-1989. In: McNicholl MK, CranmerByng JL (eds.). Ornithology in Ontario. Special Publication, Ontario Field Ornithologists, Number 1. Hawk Owl Press, Whitby. p 112-148.

14. McNicholl MK (1994b) Brief biographies of Ontario bird banders. In: McNicholl MK, Cranmer-Byng $\mathrm{JL}$ (eds.). Ornithology in Ontario. Special Publication, Ontario Field Ornithologists, Number 1. Hawk Owl Press, Whitby. p 315-394.

15. Bastian SF (2008) Collecting the guide. Last accessed on December 22, 2012 from: http://www.rtpi.org/index. php?option $=$ com_content $\&$ view $=$ article \&id $=33 \&$ Itemid $=\overline{2} 8$.

16. Allen GA (1939) [Review of]

Peterson's 'Field Guide,' by Roger Tory

Peterson.' Auk 56:348-349.
17. Clarke CHD (1939) [Review of] A Field Guide to the Birds, by Roger Tory Peterson, Houghton Mifflin, Boston, MA. Canadian Field-Naturalist 53:92-93.

18. Deignan HG (1960) Proceedings of the seventy-seventh stated meeting of the American Ornithologists' Union. Auk 77:56-63.

19. Peterson RT (1960) A prairie chicken at Old Wives Lake. Blue Jay 18:13.

20. Peterson RT, Fisher J (1955) Wild America. Houghton Mifflin Company, Boston MA.

21. Brazier F (1956) [Review of] Wild America, by Roger Tory Peterson and James Fisher. Houghton Mifflin, Boston. Blue Jay 14:72.

22. Livingston JA (1965) The cranes at Last Mountain Lake. In: Pettingill OS Jr (ed.). The birdwatcher's America. McGraw-Hill, Toronto. p. 371-377.

23. Nero RW (1965) Editor's note: far away cranes. Blue Jay 23: cover 2.

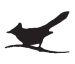

"Birding, after all, is just a game. Going beyond that is what is important." - Roger Tory Peterson 